\title{
Study of internalization and viability of multimodal nanoparticles for labeling of human umbilical cord mesenchymal stem cells
}

\author{
Estudo de internalização e viabilidade de nanopartículas multimodal para \\ marcação de células-tronco mesenquimais de cordão umbilical humano \\ Liza Aya Mabuchi Miyaki¹, Tatiana Tais Sibov², Lorena Favaro Pavon², \\ Javier Bustamante Mamani², Lionel Fernel Gamarra ${ }^{2}$
}

\begin{abstract}
Objective: To analyze multimodal magnetic nanoparticles-Rhodamine $B$ in culture media for cell labeling, and to establish a study of multimodal magnetic nanoparticles-Rhodamine $B$ detection at labeled cells evaluating they viability at concentrations of $10 \mu \mathrm{g}$ $\mathrm{Fe} / \mathrm{mL}$ and $100 \mu \mathrm{g} \mathrm{Fe} / \mathrm{mL}$. Methods: We performed the analysis of stability of multimodal magnetic nanoparticles-Rhodamine B in different culture media; the mesenchymal stem cells labeling with multimodal magnetic nanoparticles-Rhodamine $B$; the intracellular detection of multimodal magnetic nanoparticles-Rhodamine $B$ in mesenchymal stem cells, and assessment of the viability of labeled cells by kinetic proliferation. Results: The stability analysis showed that multimodal magnetic nanoparticles-Rhodamine B had good stability in cultured Dulbecco's Modified Eagle's-Low Glucose medium and RPMI 1640 medium. The mesenchymal stem cell with multimodal magnetic nanoparticles-Rhodamine $B$ described location of intracellular nanoparticles, which were shown as blue granules co-localized in fluorescent clusters, thus characterizing magnetic and fluorescent properties of multimodal magnetic nanoparticlesRhodamine B. Conclusion: The stability of multimodal magnetic nanoparticles-Rhodamine B found in cultured Dulbecco's Modified Eagle's-Low Glucose medium and RPMI 1640 medium assured intracellular mesenchymal stem cells labeling. This cell labeling did not affect viability of labeled mesenchymal stem cells since they continued to proliferate for five days.
\end{abstract}

Keywords: Mesenchymal stem cells; Nanoparticles; Rhodamines; Umbilical cord

\section{RESUMO}

Objetivo: Analisar a estabilidade das nanopartículas magnéticas multimodais-Rhodamine B em meios de cultura para marcação celular e, consequentemente, estabelecer o estudo de detecção intracelular de nanopartículas magnéticas multimodais-Rhodamine $B$ nas células marcadas, avaliando a viabilidade celular nas concentrações de $10 \mu \mathrm{g} \mathrm{Fe} / \mathrm{mL}$ e $100 \mu \mathrm{g} \mathrm{Fe} / \mathrm{mL}$. Métodos: Foram realizados: análise da estabilidade das nanopartículas magnéticas multimodais-Rhodamine B em meios de cultura diferentes; marcação das células-tronco mesenquimais com nanopartículas magnéticas multimodaisRhodamine B; detecção intracelular das nanopartículas magnéticas multimodais-Rhodamine $B$ nas células-tronco mesenquimais $e$ avaliação da viabilidade das células marcadas por meio da cinética de proliferação. Resultados: $A$ análise de estabilidade determinou que as nanopartículas magnéticas multimodais-Rhodamine $B$ presentes nos meios de cultura Dulbecco's Modified Eagle's-Low Glucose e RPMI Medium 1640 apresentaram boa estabilidade. A marcação das células-tronco mesenquimais com nanopartículas magnéticas multimodais-Rhodamine B descreveu localização intracelular das nanopartículas, as quais se mostraram como grânulos azulados colocalizados nos grumos fluorescentes, caracterizando, assim, as propriedades magnéticas e fluorescentes das nanopartículas magnéticas multimodais-Rhodamine B. Conclusão: $A$ estabilidade das nanopartículas magnéticas multimodais-Rhodamine $B$, presentes nos meios de cultura Dulbecco's Modified Eagle's-Low Glucose e RPMI Medium 1640, garantiu a eficiente marcação intracelular das células-tronco mesenquimais. Esse tipo de marcação não afetou

Study carried out at the Instituto Israelita de Ensino e Pesquisa Albert Einstein, Hospital Israelita Albert Einstein - HIAE, São Paulo (SP), Brazil.

1 Instituto do Cérebro - InCe, Hospital Israelita Albert Einstein - HIAE, São Paulo (SP), Brazil; Faculdade de Enfermagem do Hospital Israelita Albert Einstein - HIAE, São Paulo (SP), Brazil.

2 Instituto do Cérebro - InCe, Hospital Israelita Albert Einstein - HIAE, São Paulo (SP), Brazil.

Corresponding author: Tatiana Tais Sibov - Instituto do Cérebro - InCe, Hospital Israelita Albert Einstein - Avenida Albert Einstein, 627/701, Piso Chinuch, 2 Subsolo - Morumbi - Zip code: 05651-901 - São Paulo (SP), Brazil - Phone.: (55 11) 2151-3727 -E-mail: tatianats@einstein.br

Received on: Mar 1, 2012 - Accepted on: Jun 13, 2012

Conflict of interests: none. 
viabilidade das células-tronco mesenquimais marcadas, já que as mesmas continuaram proliferando ao longo de 5 dias.

Descritores: Células-tronco mesenquimais; Nanopartículas; Rodaminas; Cordão umbilical

\section{INTRODUCTION}

Mesenchymal stem cells (MSCs) are multipotent cells which are capable to originate other cell types such as adipocytes, osteoblasts and chondrocytes ${ }^{(1-4)}$. Besides that, the importance of the use of such cells in cell therapy is because MSC have other important features like the easily to isolate, expansion, handling and immunosuppressive properties ${ }^{(4-8)}$.

The MSC when compared with other types of stem cells ${ }^{(9)}$ presents some clinical advantages because it could be promptly acquired from patients, easily expanded ex vivo as well as autotransfuded without risk of immunologic rejection and free from ethical concerns $^{(10,11)}$.

Bone marrow (BM) is the primary and most studied source to obtain MSCs used in clinical and experimental applications. However, there are studies showing that MSCs from the wall of human umbilical cord (WHUC) have morphological features, immunophenotypes and the ability to differentiate in cell from mesodermal lineages, similar to MSCs from $\mathrm{BM}^{(2,4,12-14)}$.

Therefore, the MSCs constitute an important and promising therapeutic tool to treat neurocardivascular, neurodegenerative, hematologic and immunodeficient diseases to which specific and effective treatment is not available or still unknown ${ }^{(15-18)}$. Although, in vivo follow-up of these cells behavior remains a barrier for its use in cell therapy.

The chance to establish an efficient labeling of these cells with iron oxide nanoparticles (ION) without loss of viability may provide non-invasive methods for in vivo follow-up of these cells. Thus, nanobiotechnology innovation promotes the study of new tools to biomedical advances.

Nanostructured materials are systems constituted of particles of nanometric dimensions. The interest for these materials in nanobiotechnology rely on the fact of the special biophysical properties presented when compared with the same materials composed by large particles ${ }^{(19)}$. In such context, the ION has become an innovative nanobiotechnological resource in the process of cell labeling and its posterior study by molecular imaging ${ }^{(20,21)}$.
Recently the process used to follow-up migration or homing of MSCs is these cells labeling with $\mathrm{ION}^{(20)}$. This process enables to follow-up MSCs distribution and destiny as well as to maximize their therapeutic benefits $^{(20-22)}$.

Some studies ${ }^{(23,24)}$ show the use of multimodal magnetic nanoparticles (MMNPs) defined as nanoparticles that present magnetic and fluorescent properties (Rhodamine B - RhB, BioPAL, Worcester, MA, USA) which might be shown by magnetic resonance imaging (MRI) and fluorescence microscopy.

The MMNPs have fluorescence features because they are conjugated with fluorescence elements like ION conjugated with $\mathrm{RhB}$ (two fluorophores per particles) in which emission wavelength is 565 to $620 \mathrm{~nm}$. These MMNPs (RhB) have a magnetic core of $8 \mathrm{~nm}$ with a hydrodynamic size of $35 \mathrm{~nm}$, zeta potential of $-31 \mathrm{nV}$ and concentration of $2 \mathrm{mg}$ of $\mathrm{Fe} / \mathrm{mL}$ (BioPAL, Worcester, MA, USA).

In this study we established the detection of intracellular of MMNPs (RhB), assessing the viability of cell labeling in MSCs and WHUC with different nanoparticles concentrations $(10 \mu \mathrm{g} \mathrm{Fe} / \mathrm{mL}$ and $100 \mu \mathrm{g}$ $\mathrm{Fe} / \mathrm{mL}$ ), and its stability in different culture media.

\section{OBJECTIVE}

This study aimed to analyze the MMNP (RhB) stability in culture media for cell labeling and also to establish a study of intracellular MMNP detection in labeled cells evaluating they viability at concentrations of $10 \mu \mathrm{g} \mathrm{Fe} / \mathrm{mL}$ and $100 \mu \mathrm{g} \mathrm{Fe} / \mathrm{mL}$.

\section{METHODS}

\section{Collection and processing of umbilical cord sample}

The WHUC samples were collected after donor's mother signing the informed consent according to the rules of Ethical and Research Committee of the Instituto Israelita de Ensino e Pesquisa Albert Einstein (IIEPAE), numbers SGPP: 683-09; CEP: 1059. The sample was collected by umbilical cord cuts after birth and stored in Phosphate Buffered Saline 1x (PBS, Sigma-Aldrich) with $10 \mathrm{mM}$ of EDTA anticoagulant and after that it was processed until 6 hours after collection. After washing the umbilical cord vein twice with PBS 1x (Sigma-Aldrich), the MSC were taken from the sample by enzymatic digestion using collagenase type I (Sigma-Aldrich) for 30 minutes at $37^{\circ} \mathrm{C}$ in $5 \%$ of $\mathrm{CO}_{2}$. Later, the enzyme was inactivated with fetal bovine serum (Gibco ${ }^{\circledR}$, Invitrogen Corporation), and 
the isolated cells were kept in Dulbecco's Modified Eagle’s-low glucose medium (DMEM-LG, Gibco ${ }^{\circledR}$, Invitrogen Corporation).

\section{Culture of MSC from the WHUC}

The isolated MSCs were plated in plates of $25 \mathrm{~cm}^{2}$ in a cellular density of $10^{7}$ cells $/ \mathrm{cm}^{2}$ containing DMEMLG (Gibco $^{\circledR}$, Invitrogen Corporation) medium, and supplemented with $200 \mathrm{mM}$ of L-Glutamina, antibiotical/antimicotical $10.000 \mathrm{U} / \mathrm{mL}$ serum penicillin, $10.000 \mu \mathrm{g} / \mathrm{mL}$ streptomycin sulfate, $25 \mu \mathrm{g} / \mathrm{mL}$ amphotericin B (Gibco ${ }^{\circledR}$, Invitrogen Corporation) and 10\% Fetal Bovine Serum $\left(\mathrm{Gibco}^{\circledR}\right.$, Invitrogen Corporation). The MSCs cultures were kept in incubator (Thermo Fisher Scientific Inc 3110 , Waltham, MA) at $37^{\circ} \mathrm{C}$ in $5 \%$ of $\mathrm{CO}_{2}$, and the non-adherent cells removed from the culture plate after 24 hours. The experiments were done at fourth cell culture passage with approximately $80 \%$ of confluence.

\section{Immunophenotypes features of MSC from the WHUC}

The isolated MSC were characterized by flow cytometry immunophenotyping. The labeling method used addressed manufacturer's instructions. The cells were labeled with monoclonal antibodies, and they were incubated for 30 minutes in darkness at room temperature. After incubation cells were washed and fixed with $1 \%$ paraformaldehyde. The monoclonal antibodies used were: CD14 FITC clone:M5E2 (BD Pharmingen, San Diego, CA); CD29 PE clone:MAR4 (BD Pharmingen, San Diego, CA); CD31 PE clone:WM59 (BD Pharmingen, San Diego, CA); CD45 PerCP CY5.5 clone:2D1 (BD Biosciences, San Jose, CA); CD73 PE clone:AD2 (BD Pharmingen, San Diego, CA); CD105 PE clone:43A3 (Biolegend, San Diego, CA); CD90 APC clone:5E10 (BD Pharmingen, San Diego, CA); HLA-A,B e C FITC clone:G46-2.6 (BD Pharmingen, San Diego, CA); CD106 FITC clone:51-10C9 (BD Pharmingen, San Diego, CA); CD133 APC clone:293C3 (Myltenyi Biotec, Germany); and isotypes controlled. Data were collected using a FACSARIA (BD Biosciences, San Jose, CA) flow cytometer, and the results analyzed with FACSDIVA software (BD Biosciences) and FLOWJO (Tree Star, Ashland, OR).

\section{Stability analysis of MMPN (RhB) in culture media}

The stability analysis of MMPN was cultured in DMEM-LG medium (Gibco ${ }^{\circledR}$, Invitrogen Corporation) and RPMI 1640 medium $\left(\right.$ Gibco $^{\circledR}$, Invitrogen Corporation) aiming to evaluate the more adequate mean to study the MMPN labeling (RhB) in MSC, because these culture media are most mentioned cell labeling process in the literature ${ }^{(25-28)}$. Study of stability was done using the Dynamic Light Scattering (DLS) technique with measures of temporal distribution of hydrodynamic size of MMPN (RhB) using a Malvern Zetasizer NanoS (Malvern, UK). Characterization of hydrodynamic size distribution was obtained at $173^{\circ}$ manually angle average of 20 and time of 5 seconds per medium. Measurements were done on fixed position and at $37^{\circ} \mathrm{C}$ with equilibrium time of 60 seconds. We used $2 \mathrm{ml}$ of each culture medium at concentration of 10 and $100 \mu \mathrm{gFe} / \mathrm{mL}$, and in the control group $2 \mathrm{ml}$ of Milli-Q water with concentration of $100 \mu \mathrm{gFe} / \mathrm{mL}$. The measures of hydrodynamic size were done at different times within intervals of 0 to 20 hours. The analysis of size distribution was set after shape of correlation function of scattered light intensity with the CONTIN algorithm.

\section{MSC labeling with MMPN (RhB)}

Approximately $1 \times 10^{5}$ MSCs were platted in 24 wells plates and left in incubator overnight (Thermo Fisher Scientific Inc 3110 , Waltham, MA) at $37^{\circ} \mathrm{C}$ in $5 \%$ of $\mathrm{CO}_{2}$, and suspended in MMNP (RhB) in triplicate at concentrations of $10 \mu \mathrm{g} \mathrm{Fe} / \mathrm{mL}$ and $100 \mu \mathrm{g} \mathrm{Fe} / \mathrm{mL}$. After the incubation period, the MMPN (RhB) solution culture medium was taken by aspiration and MSCs were washed twice with PBS (1x) to take off extracellular MMPN (RhB). The controlled cells were processed with culture medium only, however, using the same conditions of labeled ones.

\section{Intracellular detection of MMNP (RhB)}

The labeled MSCs were washed with PBS 1x (SigmaAldrich) to take off excess of particles and then they were fixed with $4 \%$ paraformaldehyde. Subsequently, we did a 5\% Prussian blue cytochemical assessment, solution of 5\% Potassium ferrocyanide (SigmaAldrich)/solution of $5 \%$ of HCI $37 \%$ (Merck, Germany) and basic fuchsin (Sigma-Aldrich) to check internalization of particles in MSCs. The analysis was done using a fluorescence microscopy (IX51 Olympus). First using regular microscopy, and in parallel using a Rhodamine filter $(530 \mathrm{~nm}$ and $550 \mathrm{~nm})$. 


\section{Kinetic proliferation}

Approximately $5 \times 10^{4} \mathrm{MMNP}(\mathrm{RhB})$ were incubated in triplicate at concentrations of $10 \mu \mathrm{g} F / \mathrm{mL}$ and $100 \mu \mathrm{g} \mathrm{Fe} / \mathrm{mL}$. Then, cells were washed twice with PBS 1x (Sigma-Aldrich) and kept in the incubator (Thermo Fisher Scientific Inc 3110, Waltham, MA) at $37^{\circ} \mathrm{C}$ in $5 \%$ of $\mathrm{CO}_{2}$. For five days, triplicate of each concentration was washed with PBS (1x) (SigmaAldrich) and labeled MSCs were took by enzymatic digestion using the $0.25 \%$ trypsin-EDTA $\left(\mathrm{Gibco}^{\oplus}\right.$, Invitrogen Corporation) for 3 minutes at $37^{\circ} \mathrm{C}$ of $5 \%$ of $\mathrm{CO}_{2}$. The enzymatic inactivation was performed using DMEM-LG, 10\% Fetal Bovine Serum $\left(\right.$ Gibco $^{\oplus}$, Invitrogen Corporation). Cells were resuspended and quantified via Newbauer chamber. Total of cell from each point in the curve was expressed by mean in triplicates.

\section{RESULTS}

Morphologic and immunophenotypic features of MSC from the WHUC

MSCs from the WHUC had fibroblast morphology and reached confluence between 80 and $90 \%$ in 7 days of culture (Figure 1). The immunophenotypic profile of isolated MSCs from the WHUC is presented in other papers already published by our group ${ }^{(2,4)}$.

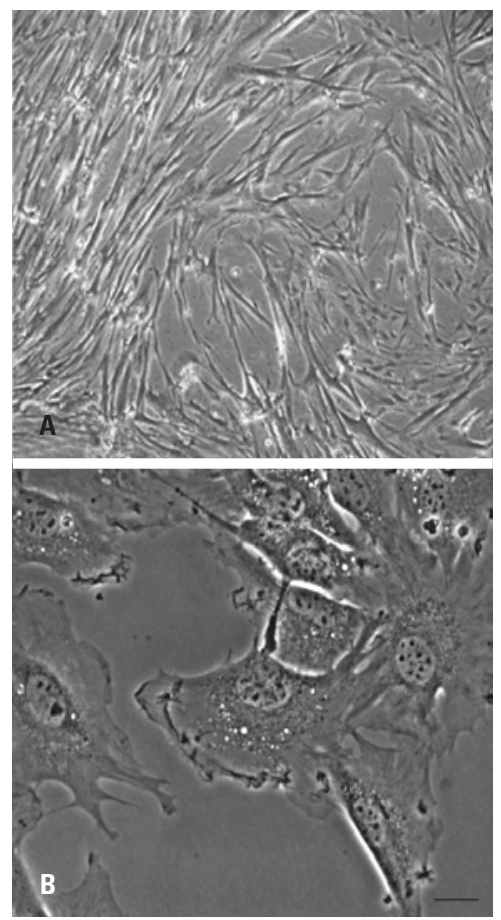

Figure 1. Isolated mesenchymal stem cells from the wall of human umbilical cord. (A) Mesenchymal stem cells culture with approximately $90 \%$ confluence, 200X; (B) Mesenchymal stem cells culture with approximately $80 \%$ confluence, $600 X$

\section{MMNP (RhB) stability cultured in DMEM-LG and RPMI}

Along time hydrodynamic size variation (resulted from agglomeration of MMNP dispersed in liquid) determines the instability of MMNP, and as consequence, decreases the efficiency to catch the MMPN (RhB) from MSCs. Thus, DLS measures were performed to determine the variability of hydrodynamic size of MMNP (RhB) dispersed in DMEM and RPMI culture media at concentration of 10 and $100 \mathrm{ug} / \mathrm{mL}$ and from the control sample at different time, as shown in figure 2 .

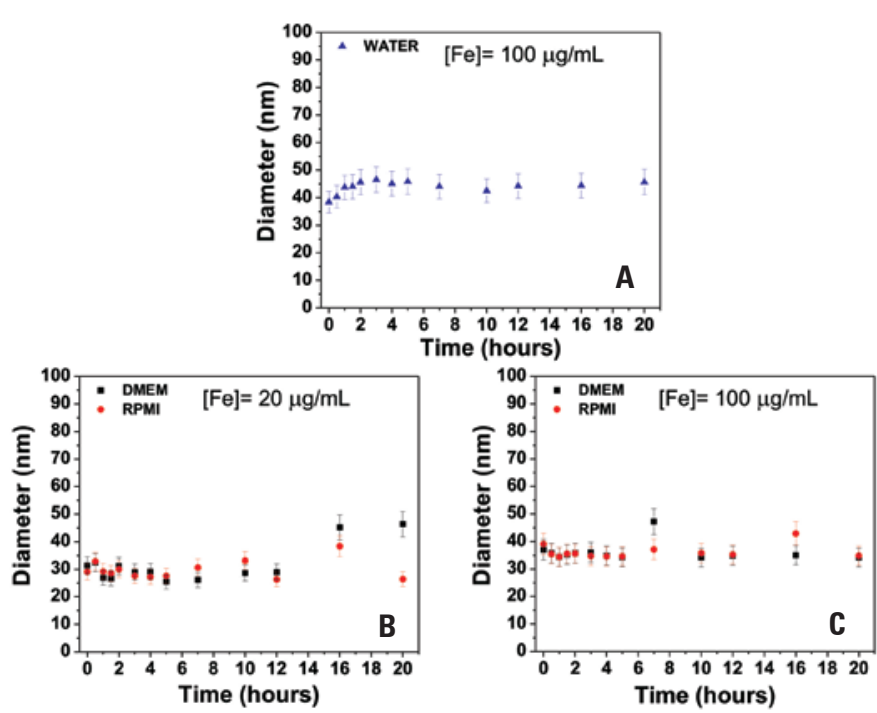

Figure 2. Measures of hydrodynamic size variability of multimodal magnetic nanoparticles (Rhodamine B) from 0 until 20 hours. (A) Multimodal magnetic nanoparticles (Rhodamine B) suspended in water at concentrations of $100 \mu \mathrm{g} \mathrm{Fe} / \mathrm{mL}$ (control sample). ) Multimodal magnetic nanoparticles (Rhodamine B) dispersed in DMEM and RPMI culture media at concentration of (B) $10 \mu \mathrm{g} \mathrm{Fe} / \mathrm{mL}$ and (C) $100 \mu \mathrm{g} \mathrm{Fe} / \mathrm{mL}$

\section{Detection of intracellular MMNP $(\mathrm{RhB})$ in MSC}

An evaluation of intracellular distribution of nanoparticles with magnetic and fluorescence properties, used for MSCs labeling, was done via Prussian blue cytochemical assessment and basic fuchsin via optical and fluorescent microscopy.

We observed in cytochemical assessments the internalization of MMNP (RhB) as blue granules of intracellular location (Figures 3B to $3 \mathrm{D}, 3 \mathrm{H}$ to $3 \mathrm{~J}$ ). This process was observed in negative control, in other words, unlabeled MSCs (Figures 3A and 3G).

The detection of intracellular MMNP (RhB) was also observed in labeling using the fluorescent microscopy (Figures 3E, 3F, 3L to $3 \mathrm{~N}$ ). The particles were presented as small fluorescent clusters of co-localization with blue granules indicated by cytochemical tests (Figures $3 \mathrm{H}$ and $3 \mathrm{~L}$ ). 


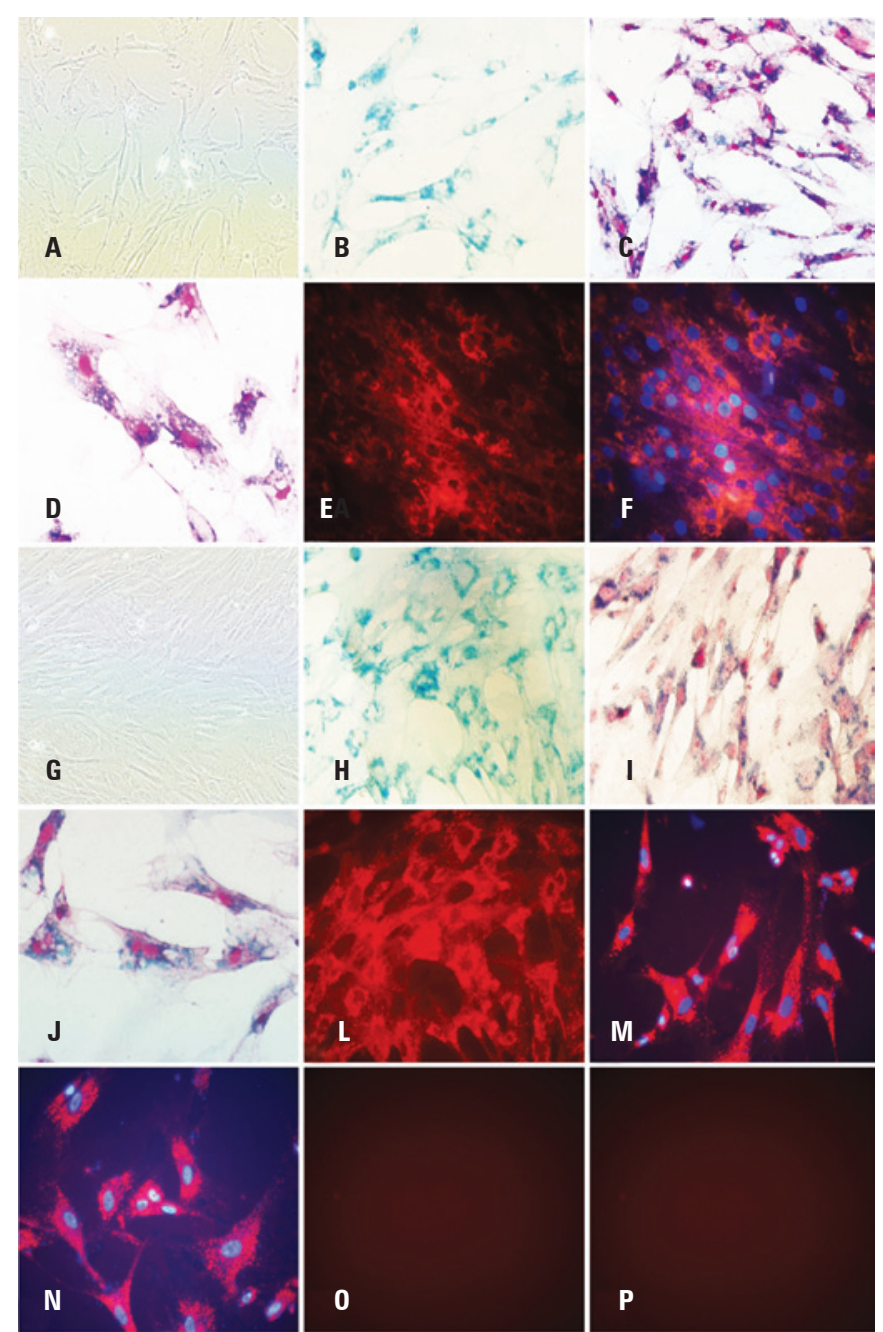

Figure 3. Mesenchymal stem cells labeling with multimodal magnetic nanoparticles (Rhodamine B). (B and F) Suspended multimodal magnetic nanoparticles (Rhodamine B) at concentration of $10 \mu \mathrm{g} \mathrm{Fe} / \mathrm{mL}$. ( $\mathrm{H}$ and N) Suspended multimodal magnetic nanoparticles (Rhodamine B) at concentration of $100 \mu \mathrm{g} \mathrm{Fe} / \mathrm{mL}$. (A and G) Control: culture of mesenchymal stem cells without intracellular distribution of multimodal magnetic nanoparticles (Rhodamine B), increased: 100X. (B and H) Cytochemical: Prussian blue, increased: 100X. (C, D, I and J) Cytochemical: basic fuchsin. ( $C$ and I) increased: 100X. (D and J) Increased: 400X. (E and L) Fluorescence microscopy revealing multimodal magnetic nanoparticles (Rhodamine B), increased: 200X. (F, M and N) Fluorescence microscopy revealing multimodal magnetic nanoparticles (Rhodamine $\mathrm{B}$ ) and the nucleus of mesenchymal stem cells (DAPI); (F) increased: 200X. (M and N) increased: 400X. (0 and P) Control of fluorescence microscopy reactions

\section{Labeled MSC viability}

The labeled MSC with MMNP (RhB) viability was assessed on kinetics of cell proliferation (Figure 4). The labeled MSC ability to proliferate did not reveal significant changes in the two days that comprised platting $\left(5.0 \times 10^{4}\right.$ cells/well), labeling with MMNP $(\mathrm{RhB})\left(4.93 \times 10^{4}\right.$ cells/well $)$ and in the first day $\left(5.0 \times 10^{4}\right.$ cells/well), set in the curve at concentrations $\mathrm{C} 10$ $\left(4.92 \times 10^{4}\right.$ cells/well $), \mathrm{C} 100\left(4.80 \times 10^{4}\right.$ cells/well $)$ and control $\left(5.32 \times 10^{4}\right.$ cells/well $)$.

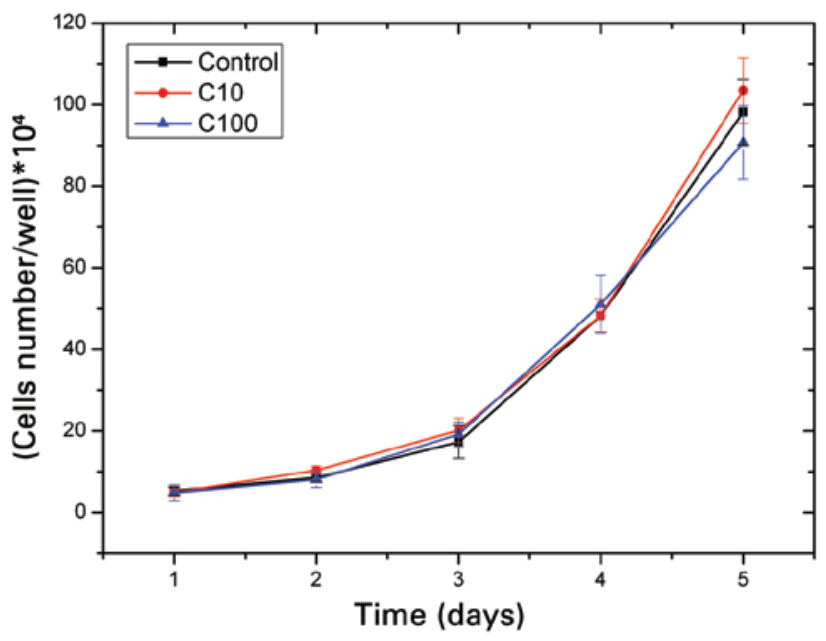

Figure 4. Kinetic proliferation of labeled mesenchymal stem cells with multimodal magnetic nanoparticles (Rhodamine B). Proliferation curve of labeled cells in triplicate at concentration of $\mathrm{C} 10=10 \mu \mathrm{g} \mathrm{Fe} / \mathrm{mL}$ and $\mathrm{C} 100=100 \mu \mathrm{g} \mathrm{Fe} / \mathrm{mL}$

\section{DISCUSSION}

The MSCs, which is also defined as multipotent progenitor cells, had the ability to differentiate in some lineages derived from the mesoderm, such as adipocytes, osteoblasts and chondrocytes ${ }^{(29-31)}$. In addition, some data in literature suggest that MSCs might derive other types of cells like cardiomyocytes ${ }^{(32-34)}$, endothelial cells $^{(35)}$ and even cells of nonmesodermal derivation including hepatocytes ${ }^{(36)}$, nerve cells ${ }^{(37)}$, and epithelial cells ${ }^{(38,39)}$. For this reason, the potential use of MSCs from the WHUC has become of important interest for many biomedical disciplines including emerging fields applied to nanotechnology, narrowing new resources to study in vitro and in vivo molecular imaging.

Therefore, this study assessed the stability of MMPN (RhB) using two different culture media for MSC labeling, and because the use of several other culture media can be found in the literature, here we show the best medium to be used. To achieve this outcome, we did a study to detect intracellular labeled MSC with MMNP (RhB) and the viability of these markers using a kinetic of cell proliferation. The results obtained in the study of stability of MMPN $(\mathrm{RhB})$ cultured in DMEM-LG and RPMI medium showed that nanoparticles are stable in both culture media, however, in this study DMEM-LG medium was chosen because this is the most used medium for culture of MSC according to the literature ${ }^{(25,26,40,41)}$.

The stability of MMNP (RhB) in liquid was analyzed using graphs of hydrodynamic diameter of particles due to time, which is presented in figure 2. The stability of MMPN (RhB) suspended in 
water at concentration of $\mathrm{C} 100=100 \mu \mathrm{g} \mathrm{Fe} / \mathrm{mL}$, here named control sample, is showed in figure $2 \mathrm{~A}$. In this figure is possible to observed, considering the uncertainty margin, that hydrodynamic diameter remains constantly, so excluding the formation of MMNP (RhB) aggregations. The measure was done to experimentally determine the hydrodynamic diameter and dispersibility of MMNP (RhB). The stability of MMNP (RhB) in water depends on particle size to avoid precipitation due to gravitational forces and chemical changes on particle surface that result on steric and Coulomb repulsion increase. Stability is derived from a delicate equilibrium of attractive and repulsive interactions among MMNP (RhB). The magnetic dipolar interaction and the Van der Waals are attractive, although the most important repulsive interactions are spherical and electrostatic. The equilibrium among interactions from opposite nature and present in a colloidal suspension of MMNP $(\mathrm{RhB})$ is modulated by Brownian motion associated to nanoparticles dispersed in water ${ }^{(42)}$.

The figures $2 \mathrm{~B}$ and $2 \mathrm{C}$ show the behavior of hydrodynamic diameter along time of dispersed MMNP cultured in DMEM-LG and RPMI medium at concentration of $\mathrm{C} 10=10$ and $\mathrm{C} 100=100 \mu \mathrm{g} \mathrm{Fe} / \mathrm{mL}$, respectively.

After analyze the hydrodynamic diameter presented as time constant value, considering the uncertainty of measures, it was possible to affirm that MMNP (RhB) were stable at concentration used, and also that there was not influence of the culture medium chosen in stability nor in formation of MMNP (RhB) aggregation. The most important features for intracellular labeling with MMNP (RhB) dispersed in culture medium is its stability, that is, these nanoparticles properties remains suspected as isolated entities (single-domains), therefore avoiding nanoparticles agglomeration and subsequent precipitation. In such case, it is possible to conclude that due to MMNP (RhB) dispersion in culture medium, a mild imbalance of forces that interact among these nanoparticles like attractive and repulsive forces of Van der Waals, electrostatic forces and forces resulting from adsorbed polymers ${ }^{(43)}$, which have little influence on stability of MMNP $(\mathrm{RhB})$ in culture medium, guarantee an efficient intracellular labeling. Therefore, MMNP (RhB) are ideal for effective intracellular labeling at culture media used, particularly because the lack of MMNP $(\mathrm{RhB})$ agglomeration suggested a good stability for incubation periods over 20 hours.
Thus, using culture media that gave stability to MMNP (RhB) the labeling of MSCs with those nanoparticles was detected by cytochemical assessments (Prussian blue and basic fuchsin) and fluorescence miscrocopy, which described intracellular localization of distributed nanoparticles by cell cytoplasm, mainly around the nucleus as blue granulous co-localizaded to fluorescent clusters, therefore, characterizing the magnetic and fluorescence properties of MMNP (RhB).

Here, we also described in which condition the study with concentration of $\mathrm{C} 100=100 \mathrm{ugFe} / \mathrm{mL}$ had a mild distribution of nanoparticles higher than that with $\mathrm{C} 10=10 \mu \mathrm{g} \mathrm{Fe} / \mathrm{mL}$.

The labeled MSC viability were not affected because the proliferation curve of them showed that cells continued to grow for 5 days in the culture under 2 different concentrations (C10 and C100).

These results are in agreement with Addicott et al. ${ }^{(23)}$ findings about the viability of labeling MSCs in vitro. Although, those authors reported that at concentration over $30 \mu \mathrm{g} \mathrm{Fe} / \mathrm{mL}$ there was a decrease of MSC viability until $78.8 \%$ to $\mathrm{C} 100$, which was not observed in our study (Figure 4).

In this study we established relevant basic results to develop an efficient MSC with MMNP (RhB) labeling protocol. already showing the non-cytotoxicity of this labeling type by the growing of proliferative curve of labeled MSCs.

\section{CONCLUSION}

One important factor for internalization of MMNP $(\mathrm{RhB})$ in these cells is they stability in the culture medium. So results of the stability analysis, carried out using the ELD technique, determined that MMNP (RhB) had good stability in both culture media, DMEM-LG and RPMI, which assured an adequate intracellular labeling of MSC.

An advantage of MMNP (RhB) use is characterized by its multimodal properties, that is, such nanoparticles had a magnetic and fluorescence character. Considering that such nanoparticles are NOFs, in vivo molecular imaging studies could be used as a tool for Magnetic Resonance analysis in the process of investigating distribution and destiny of labeled cells. Such resource could be associated to ex vivo essays using fluorescence microscopy tests in order to validate the findings of magnetic resonance study of MMPN (RhB) localization, which could enlarge the possible benefits of therapy attached to MSCs. 


\section{ACKNOWLEDGMENT}

Research funding sources: São Paulo Research Foundation (FAPESP), process \# 2011/17644-2, Projects and Studies Fund (FINEP), Coordination for the Improvement of Higher Education Personnel (CAPES) and National Counsel of Technological and Scientific Development (CNPq).

\section{REFERENCES}

1. Kiessling A, Anderson SC. Human embryonic stem cells. Sudbury (MA): Jones and Bartlett; 2003.

2. Sibov TT, Pavon LF, Oliveira DM, Marti LC, Guilhen DD, Amaro E Jr, et al. Characterization of adherent umbilical cord blood stromal cells regarding passage, cell number, and nano-biomarking utilization. Cell Reprogram. 2010; 12(4):391-403.

3. Can A, Balci D. Isolation, culture, and characterization of human umbilical cord stroma-derived mesenchymal stem cells. Methods Mol Biol. 2011;698:51-62.

4. Sibov TT, Severino P, Marti LC, Pavon LF, Oliveira DM, Tobo PR, et al. Mesenchymal stem cells from umbilical cord blood: parameters for isolation, characterization and adipogenic differentiation. Cytotechnology. 2012 Feb 12 [Epub ahead of print]. DOI 10.1007/s10616-012-9428-3.

5. Bieback K, Kern S, Klüter H, Eichler H. Critical parameters for the isolation of mesenchymal stem cells from umbilical cord blood. Stem Cells. 2004; 22(4):625-34.

6. Chamberlain G, Fox J, Ashton B, Middleton J. Concise review: mesenchymal stem cells: their phenotype, differentiation capacity, immunological features, and potential for homing. Stem Cells. 2007;25(11):2739-49.

7. Ng F, Boucher S, Koh S, Sastry KS, Chase L, Lakshmipathy U, et al. PDGF, TGF-beta, and FGF signaling is important for differentiation and growth of mesenchymal stem cells (MSCs): transcriptional profiling can identify markers and signaling pathways important in differentiation of MSCs into adipogenic, chondrogenic, and osteogenic lineages. Blood. 2008;112(2): 295-307. Comment in: Blood. 2008;112(2):217-8.

8. da Silva Meirelles L, Caplan Al, Nardi NB. In search of the in vivo identity of mesenchymal stem cells. Stem Cells. 2008;26(9):2287-99.

9. Aboody KS, Brown A, Rainov NG, Bower KA, Liu S, Yang W, et al. Neural stem cells display extensive tropism for pathology in adult brain: evidence from intracranial gliomas. Proc Natl Acad Sci U S A. 2000;97(23):12846-51. Erratum in: Proc Natl Acad Sci U S A 2001;98(2):777.

10. Caplan Al, Bruder SP. Mesenchymal stem cells: building blocks for molecular medicine in the 21st century. Trends Mol Med. 2001;7(6):259-64.

11. Tocci A, Forte L. Mesenchymal stem cell: use and perspectives. Hematol J. 2003;4(2):92-6.

12. Covas DT, Siufi JL, Silva AR, Orellana MD. Isolation and culture of umbilical vein mesenchymal stem cells. Braz J Med Biol Res. 2003;36(9):1179-83.

13. Covas DT, Panepucci RA, Fontes AM, Silva WA Jr, Orellana MD, Freitas MC, et al. Multipotent mesenchymal stromal cells obtained from diverse human tissues share functional properties and gene-expression profile with CD146+ perivascular cells and fibroblasts. Exp Hematol. 2008;36(5):642-54.

14. Kestendjieva S, Kyurkchiev D, Tsvetkova G, Mehandjiev T, Dimitrov A, Nikolov $A$, et al. Characterization of mesenchymal stem cells isolated from the human umbilical cord. Cell Biol International. 2008;32(7):724-32.

15. Kassem M. Mesenchymal stem cells: biological characteristics and potential clinical applications. Cloning Stem Cells. 2004;6(4):369-74.

16. Schilling T, Nöth U, Klein-Hitpass L, Jakob F, Schütze N. Plasticity in adipogenesis and osteogenesis of human mesenchymal stem cells. Mol Cell Endocrinol. 2007;271(1-2):1-17.

17. Kim SS, Yoo SW, Park TS, Ahn SC, Jeong HS, Kim JW, et al. Neural induction with neurogenin1 increases the therapeutic effects of mesenchymal stem cells in the ischemic brain. Stem Cells. 2008;26(9):2217-28.

18. Andrews EM, Tsai SY, Johnsonb SC, Farrer JR, Wagner JP, Kopen GC, et al. Human adult bone marrow-derived somatic cell therapy results in functional recovery and axonal plasticity following stroke in the rat. Exp Neurol. 2008;211(2):588-92.

19. Salata 0 . Applications of nanoparticles in biology and medicine. J Nanobiotechnology. 2004;2(1):3.

20. Kosztowski T, Zaidi HA, Quiñones-Hinojosa A. Applications of neural and mesenchymal stem cells in the treatment of gliomas. Expert Rev Anticancer Ther. 2009;9(5):597-612.

21. Chien LY, Hsiao JK, Hsu SC, Yao M, Lu CW, Liu HM, et al. In vivo magnetic resonance imaging of cell tropism, trafficking mechanism, and therapeutic impact of human mesenchymal stem cells in a murine glioma model. Biomaterials. 2011;32(12):3275-84.

22. Wu SY, Ferkowicz M, McClay DR. Ingression of primary mesenchyme cells of the sea urchin embryo: a precisely timed epithelial mesenchymal transition. Birth Defects Res C: Embryo Today. 2007;81(4):241-52.

23. Addicott B, Willman M, Rodriguez J, Padgett K, Han D, Berman D, et al. Mesenchymal stem cell labeling and in vitro MR characterization at $1.5 \mathrm{~T}$ of new SPIO contrast agent: Molday ION Rhodamine $\mathrm{B}^{\mathrm{TM}}$. Contrast Media \& Molecular Imaging. 2011;6(1):7-18. doi: 10.1002/cmmi.396. Epub 2010 Aug 5.

24. Souza KC, Mohallem ND, Sousa EM. Nanocompósitos magnéticos: potencialidades de aplicações em biomedicina. Quím Nova. 2011;34(10): 1692-703.

25. Mahmoudi M, Simchi A, Milani AS, Stroeve P.Cell toxicity of superparamagnetic iron oxide nanoparticles. J Colloid Interface Sci. 2009;336(2):510-8.

26. Jiang J, Fan CY, Zeng BF. Experimental construction of BMP2 and VEGF gene modified tissue engineering bone in vitro. Int J Mol Sci. 2011;12(3): 1744-55.

27. Wilhelm C, Gazeau F. Universal cell labelling with anionic magnetic nanoparticles. Biomaterials. 2008;29(22):3161-74.

28. Rivière $C$, Boudghène FP, Gazeau F, Roger J, Pons JN, Laissy JP, et al. Iron oxide nanoparticle-labeled rat smooth muscle cells: cardiac MR imaging for cell graft monitoring and quantitation. Radiology. 2005;235(3):959-67.

29. Pittenger MF, Mackay AM, Beck SC, Jaiswal RK, Douglas R, Mosca JD, et al. Multilineage potential of adult human mesenchymal stem cells. Science. 1999;284(5411):143-7.

30. Alhadlaq A, Mao JJ. Tissue-engineered neogenesis of human-shaped mandibular condyle from rat mesenchymal stem cells. J Dent Res. 2003; 82(12):951-6.

31. Gao J, Caplan Al. Mesenchymal stem cells and tissue engineering for orthopaedic surgery. Chir Organi Mov. 2003:88(3):305-16.

32. Wakitani S, Saito T, Caplan Al. Myogenic cells derived from rat bone marrow mesenchymal stem cells exposed to 5-azacytidine. Muscle Nerve. 1995;18(12):1417-26.

33. Makino S, Fukuda K, Miyoshi S, Konishi F, Kodama H, Pan J, et al. Cardiomyocytes can be generated from marrow stromal cells in vitro. J Clin Invest. 1999;103(5):697-705.

34. Planat-Bénard V, Menard C, André M, Puceat M, Perez A, Garcia-Verdugo JM, et al. Spontaneous cardiomyocyte differentiation from adipose tissue stroma cells. Circ Res. 2004;94(2):223-9.

35. Oswald J, Boxberger S, Jørgensen B, Feldmann S, Ehninger G, Bornhäuser M, et al. Mesenchymal stem cells can be differentiated into endothelial cells in vitro. Stem Cells. 2004;22(3):377-84.

36. Chagraoui J, Lepage-Noll A, Anjo A, Uzan G, Charbord P. Fetal liver stroma consists of cells in epithelial-to-mesenchymal transition. Blood. 2003; 101(8):2973-82.

37. Woodbury D, Schwarz EJ, Prockop DJ, Black IB. Adult rat and human bone marrow stromal cells differentiate into neurons. J Neurosci Res. 2000;61(4): 364-70. 
38. Spees JL, Olson SD, Ylostalo J, Lynch PJ, Smith J, Perry A, et al. Differentiation, cell fusion, and nuclear fusion during ex vivo repair of epithelium by human adult stem cells from bone marrow stroma. Proc Natl Acad Sci U S A. 2003; 100(5):2397-402.

39. Ma Y, Xu Y, Xiao Z, Yang W, Zhang C, Song E, et al. Reconstruction of chemically burned rat corneal surface by bone marrow-derived human mesenchymal stem cells. Stem Cells. 2006;24(2):315-21.

40. Hsiao JK, Tai MF, Chu HH, Chen ST, Li H, Lai DM, et al. Magnetic nanoparticle labeling of mesenchymal stem cells without transfection agent: Cellular behavior and capability of detection with clinical $1.5 \mathrm{~T}$ magnetic resonance at the single cell level. Magn Reson Med. 2007;58(4):717-24.

41. Omidkhoda A, Mozdarani H, Movasaghpoor A, Fatholah AA. Study of apoptosis in labeled mesenchymal stem cells with superparamagnetic iron oxide using neutral comet assay. Toxicol In Vitro. 2007;21(6):1191-6.

42. Massart R. Preparation of aqueous magnetic liquids in alkaline and acidic media. IEEE Trans Magn. 1981;17(2):1247-8.

43. Myers D. Surfaces, interfaces, and colloids: principles and applications. New York: VCH Publishers; 1991. p.433. 